\title{
(Un)Managing Emotions at the Forefront: Stories from the Shoreham Picket Line
}

\author{
Rana Sukarieh
}

\begin{abstract}
In this article, I reflect on my experience as an active rank and file member of CUPE 3903, the union representing contract faculty and graduate students at York University in Toronto, Ontario, during the 2018 York University Strike, where I volunteered as a front-line communicator, or "car talker". Drawing on these experiences, I reflect on the ways in which picketers generally try to (un)manage the emotions of drivers passing through the picket line. My analysis is focused on a particular venue - the Shoreham picket line located at the southwest entrance of the university, and centers around my personal interactions with the drivers crossing the picket line during the morning hours from March 2018 to May 2018. My analysis aims to open up space to discuss the largely overlooked role that the emotions of the public play in shaping the picket line experience. In particular, I provide a multi-directional analysis of the encounters that occurred between the picketers and the general public at the Shoreham picket line during the 2018 strike, highlighting the multiplicity of variables, such as the environment, the pre-existing beliefs of the participants, and expressions of collective anger, which informed these encounters. In doing this, I illuminate the complexity of the intertwined relationship between emotional and cognitive framing, thereby providing a more comprehensive model for understanding the role that emotions play in social movement organizing.
\end{abstract}

\section{Keywords}

emotions, strike action, social movements, university protests, CUPE 3903

\section{Introduction}

On March 5th, 2018, members of CUPE 3903, the union representing teaching assistants, graduate assistants, and contract faculty at York University, Toronto, Ontario, started what would become the longest strike in the history of Canada's post-secondary sector. The strike ended on July 25 th, 2018, after the newly elected Ontario Conservative government legislated the union back to work. The grievances that led to the strike were related to the precarious working conditions of contract faculty, the introduction of a new and regressive funding model for teaching assistants, the cutting of almost 800 graduate assistant jobs at the university, and more general issues concerning equity and accessibility in the workplace (CUPE3903, 2018). Picketers installed a total of eight physical picket lines, one at each entrance to York University, with one exception, as well as one virtual picket line. Physical lines were considered to be either "soft" or "hard"; soft picket lines delayed the public's automobile entrance into the university's premises,

York University, Toronto, Canada

\section{Corresponding author:}

Rana Sukarieh, York University, Toronto, Canada

Email: Rana I2@yorku.ca 
therefore disrupting some of the administration's work, while hard picket lines blocked vehicles from entering into the vicinity altogether. Typically, CUPE 3903 held soft picket lines. At the Shoreham picket line in particular, strikers collectively agreed to allow two cars entry into the campus every four minutes; however, this would sometimes change depending on the traffic, the time of day, and the general atmosphere of the picket line. The virtual picket line posted strike updates on CUPE 3903's social media accounts and helped to supply the bargaining team with the research they needed to bargain on the union's behalf.

In this article, I reflect on my personal experience as an active rank and file member of CUPE 3903 during the 2018 York University Strike, where I volunteered to be a front-line communicator, or "car talker", at the Shoreham picket line at the southwest entrance to York University. More specifically, I offer a reflection on how picketers at this location attempted to (un)manage the emotions of drivers passing through the Shoreham picket line during the morning hours from March 2018 to May 2018 by examining my interactions with these drivers as a car talker. My goal is to illuminate the complexity between emotional and cognitive framing by providing a multi-directional analysis of interactions between the picketers and the general public. In my analysis, I highlight the multiplicity of variables, such as the environment, the pre-existing beliefs of the participants, and expressions of collective anger that informed these encounters. Such an analysis demonstrates the complexity of managing the picket line and thus expands the analytical scope of existing social movement literature.

Although previous research has examined the pivotal role of emotions in shaping social movements and collective actions (Goodwin, Jasper \& Poletta, 2001; Flam, 2005; Jasper, 2011; Gould 2015), few studies have investigated the micro-dynamics and interactions that inform emotional exchanges between the picketers and the general public. The importance of these micro-dynamics lies in their ability to directly influence the general atmosphere of the picket line. Interactions between picketers and the general public can facilitate or obstruct crossgroup solidarity. Positive feelings of solidarity play a central role in shaping the emotional well-being of picketers, often by encouraging them to continue fighting on behalf of their labour demands. The micro-dynamics of the encounters between picketers and the general public are also determining factors for potential violence, which has a significant effect on the longevity of picket lines. For instance, negative emotions from the public, such as anger, may elicit fear among some picketers, thus contributing to thinning picket lines. Negative public emotions also contribute to the potential demonization of the picketers in the media or among the community, which may also deter workers from picketing.

Despite their instrumental role in shaping the picket line experience, few social movement researchers have taken these variables seriously. Thus, my analysis presents a case study that addresses this lacuna in the literature, specifically by identifying the picket line as a site of sociological inquiry rife with affectual meanings that contain important critical insights. Importantly, my analysis does not engage in a discussion of the internal emotional experiences and realities of the picketers. Instead, I provide an examination of the emotional exchanges between the people picketing and those driving through the picket line, investigating how the former manages and unmanages moments when the latter engages in overt expressions of anger, frustration, and confusion, thereby maintaining (or not) a space of survivability and, at times, even solidarity and support.

This article is divided into three sections. In the first section, I briefly review the role of emotions in existing social movement literature, highlighting the bourgeoning studies of emotions in collective action (see Goodwin, Jasper \& Poletta, 2001; Aminzade \& McAdam, 2002; Flam 2005). These studies mainly stress the role that emotions play in the emergence of social movements (Jasper \& Poulsen, 1995; Jasper, 1998), specifically highlighting how emotions contribute to the recruitment (Snow \& Benford, 1992; Gould, 2015), dismissal (Norgaard, 2006) and demise (Adams, 2002) of particular forms of organizing. I argue that while such work adds necessary depth to the study of social movements, there is still a lack of consideration being given to the work that goes into managing the emotions of the general public at sites of protest, such as managing the emotions of non-picketers at a picket line. In the second section, I share personal stories from the Shoreham picket line that demonstrate the ability of 
picketers to manage the emotions of non-picketers, namely drivers, in order to get their support. Then, in the last section, I detail stories of anger, drawing attention to how drivers externalize their anger at being held up in traffic by either shaming the picketers for striking or for altogether blaming us for their grievances. Drawing on these experiences, I conclude by arguing that a multi-directional analysis of the encounters that occur between picketers and the general public during strike actions is the best method for highlighting the multiplicity of variables that inform these and similar encounters.

\section{Background}

\section{Emotions and social movement literature}

From the 1970 s to the late 1980 s, resource mobilization and political process theories dominated social movement literature. As a result, emotions have historically been absent from the analysis of social movements (Goodwin, Jasper \& Poletta, 2000). Resource mobilization and political process theories, which originated from a North American context, situate collective action within the rational choice paradigm. Resource Mobilization Theory (RMT) proposes an entrepreneurial characterization of social movements that focuses on the organizational structure, allocation of resources, and the institutional support within social movements (Buechler, 1999). More specifically, RMT is interested in: 1) How social movement participants are mobilized through the efficient use of resources (such as money, time, and human capital); 2) How particular movements attract "constituents" and turn them into "adherents", and: 3) How different movements compete over material and non-material resources (McCarthy $\&$ Zald, 1977). From this perspective, a social movement organization is considered to operate similarly to a business institution - the aim of which is to manage its resources and attract more "customers". Unsurprisingly, the role that emotions play in social movement organizing was dismissed in this paradigm, as RMT's primary focus was on examining what strategies to follow to recruit more participants into a given movement, and not to examine their internal emotional state (Goodwin, Jasper \& Poletta, 2000).

Similar to RMT, Political Process Theory (PPT) maintains that political actors in a social movement pursue their interests rationally (Tarrow, 1998; Meyer, 2004). PPT stresses that political actors mobilize when they can seize new "windows of opportunities" (Jasper, 2010, p. 966) within an emergent political environment. Such opportunities include, but are not limited to, changes in elite structure, increased access to political systems, changing or maintaining coalitions, evolving dynamics of the regime, and repression or facilitation from state apparatuses (Diani, 1995; Goodwin, Jasper \& Poletta, 2000). PPT approaches overemphasize the role of political structures in shaping social movements while also downplaying the role of individual beliefs, interests, and grievances (Jasper, 2011). Hence, similar to RMT, the role of emotions under PPT is also neglected.

Jasper (2011) identifies reasons for the relevant absence of the study of emotions in RMT and PPT. First, as a result of the prevalence of body-mind dualism in Western scholarship, it was long believed that there was a dichotomy between emotions and rationality. In turn, emotions were considered to be antagonistic to rational thought and therefore cast to the realm of non-academic thought, including the study of social movements (Jasper, 2011; Van Ness \& Summers-Effler, 2018). Second, when early studies of emotions started to emerge (Goodwin, Jasper \& Poletta, 2001; Aminzade \& McAdam, 2002), they did not develop to include a large number of subcategories of emotions. Rather, they were limited to specific feelings that often had overlapping definitions, such as anger and shame. Consequentially, even when scholarly measures for emotion became available, they held little analytical and conceptual utility.

However, over the last three decades, the study of the role of emotions in social movement organizing has become increasingly more prevalent, thereby marking a shift away from the rational paradigm that dominated social movement theories throughout the seventies and eighties (Goodwin, Jasper \& Poletta, 2001; Aminzade \& McAdam, 2002). Namely, in the early 2000s, we saw scholars begin to address the different typologies of feelings (Goodwin, Jasper \& Poletta, 2000). This was in part buttressed by the establishment of the sociology of emotions as a separate subfield of sociology in the early 1990s (Goodwin, Jasper \& Poletta, 2000; Benski, 2011), 
coupled with the rise of feminist scholars working to integrate emotions into social movement studies (Taylor, 1995). As a result of these initiatives, scholars are increasingly analyzing the effect of micro-dynamics on collective behaviour, including examining the complex ways in which emotions inform social movements (Bosco, 2006). In particular, studies have begun to highlight the role of emotions in the emergence, development, maintenance, and disintegration of social movements (Jasper \& Poulsen, 1995; Jasper, 1998; Adams, 2002; Cadena-Roa, 2002; Perry, 2002; Klatch, 2004). However, most research tends to focus on the emotions of the participants and protestors, as opposed to the emotional responses of "bystanders", such as people passing through picket lines.

One exception, however, is Tova Benski's (2011) article "Breaching events and the emotional reaction of the public". Benski offers a comprehensive analysis of the public reactions of bystanders to the Israeli Women in Black Vigil events. These vigils take place every Friday at the main roundabout in Haifa in order to protest the Israeli occupation of the Palestinian territories. These vigils originated in Jerusalem in 1988 after the onset of the first Palestinian intifada (uprising). Protestors are mainly women, wearing black, calling for an end to the Israeli occupation. The vigil events have now expanded to other cities, including the Haifa roundabout, which is the site of inquiry of Benski's study. Framing the vigil as a breaching event that defies the hegemonic social practices that constitute Israeli society, Benski records the public's general negative reactions to the Women in Black movement. Benski observes that the movement's combined politicization and feminization of the roundabout, via the vigil's use of women-identified protestors, constitutes a violation of the patriarchal systems that dominate Israeli society, while also challenging the general opinion that Israel apartheid is a form of protection - rather than a clear example of imperial violence.

As documented by Benski, the emotional expressions of the people witnessing the event are fuelled by anger, threats, and the desire to shame. In particular, Benski observes that the Israeli public uses masculine-related language to defeminize the space, thereby delegitimizing the women's claim to said space as a site of protest, while also using threats and slurs to de-humanize the women themselves.
Benski's work is notable because it combines social movement literature with the sociology of emotions to analyze - at the ground level - how public emotional reactions to a public protest (i.e. a political vigil) are informed by both normative gendered cognitive maps and general public opinion.

It is important to point out, however, that given the fact that this is a silent vigil being held at a busy roundabout in Haifa, bystanders' reactions to this particular protest are unidirectional, as those passing by do not directly interact with the protestors. That is, there is no engaged interaction between the protestors and the public. With this in mind, this paper takes Benski's analysis one step further by bridging social movement literature and the study of emotions to examine interactions between picketers and bystanders at a picket line. More specifically, this paper analyses how picketers at the Shoreham picket line during the 2018 York University Strike attempted to (un)manage the emotions of drivers passing through by mobilizing emotional and cognitive framing aimed at co-constructing feelings of solidarity. My analysis is based on my understanding of a series of moments of engaged interaction between the general public and myself, which often lasted a couple of minutes each. In what follows, I attempt to provide an analysis of these moments of engagement to develop a better understanding of how and why the public reacted at the Shoreham picket line in the ways they did.

\section{Methods}

\section{Data collection}

The data used in this article was collected through a three-month unplanned ethnography. I use the term unplanned to recognize the fact that collecting this data was the unforeseen result of my participation in the 2018 York University Strike as an active member of the rank and file of CUPE 3903, wherein I passionately fought alongside my fellow union members to assert our demands. I did not participate as a traditional researcher who sought only to collect data, but as a ground-level social justice agent with a personal investment in the action's outcome. During the strike, I participated daily at the Shoreham picket line as a front-line communicator or "car talker", whereby I routinely engaged with drivers crossing our picket line. As a "car talker," my main objective 
was to communicate our grievances to the drivers, solicit their sympathy, and to elicit their solidarity. I also joined in on other direct actions and marches held at various locations both within and outside of the university .

While I did not start the strike with the intention of writing about these experiences, I ended up writing reflections in my personal journal about my daily encounters with the drivers, which ultimately contained critical and valuable insights. Moreover, as a long-time activist and researcher in social movements, I have developed the habit of writing down and sharing my thoughts and feelings about the different collective actions in which I participate. Thus, when the strike dragged into its third week, I, in addition to journaling about my experiences, started sharing them on my personal social media accounts, such as Facebook and Twitter, mainly focusing on the positive and encouraging support we received from the general public. I found that sharing positive emotions during heightened times of conflict created positive vibes amongst the York community, especially among the active members in the strike. However, some encounters with the general public were antagonistic and also needed to be documented. Sharing these encounters provided the opportunity to highlight the everyday challenges and emotional violence picketers faced with the larger York University and North York communities. It also offered a moment to share relevant learnings with those activists seeking to learn from our struggles in order to enhance their social justice claims. Hence, given both the richness of these stories as well as the existing gaps in prevailing social movement literature around the emotional micro-dynamics between picketers and the general public (see Benski, 2011 for an exception), I decided to write this reflection piece, hoping that it would be useful for both the activist and academic world.

\section{Defining the public}

The Shoreham picket line is located at the intersection of Shoreham Road and Murray Ross Road, at the south end of York University's Keele campus (See Appendix A, Figure 1). On the right side, there is York University's tennis stadium, which leases its facilities to several companies, such as the Ontario Real Estate Association. On the left side, there is the York University hockey arena, which hosts school, provincial, and national events throughout the year. Drivers frequently cross the intersection to either reach the university campus, and its surrounding houses, or to avoid traffic on nearby streets. People driving through the campus during the duration of the 2018 strike for either of these reasons were considered to be crossing the picket line.

Individuals driving through the picket line at Shoreham were classified under four main categories. The first category is "the general public," which refers to those with no official relation to York University. This group of people constitutes what social movement theorists would refer to as "non-adherents", as they had no institutional relation to the strike (McCarthy \& Zald, 1977). Many of them were passing through the picket line to reach a destination outside of the York University facilities. For these people, the physical picket lines disrupted the flow of their daily life, resulting in unexpected delays and disturbances. During the early weeks of the strike, they often asked us questions about the nature of the picket line, its legalities, and its effectiveness. The most critical concerns and questions raised by these individuals regarded the injustice of our picket line "trapping them" and, as a result, disturbing their daily routine.

The second category includes individuals who worked either at companies and associations leasing York University facilities, such as the AVIVA center and ice arenas or with contractors for on-premises facilities. These individuals were indirectly related to York University, since their daily work generates profits for the York administration, but is not directly managed by the institution. Originally, picketers would try to communicate to this category of bystanders their (un)intentional complicity in the administration's unjust practices, and their alternative ability to exercise pressure on the administration to bargain with our union. Despite these attempts, however, after a few weeks of the strike, most of these individuals chose to leave their cars at a nearby parking lot and cross the picket line by foot.

The third category of people driving through the picket line was York University employees, who were directly impacted by the strike. While the picket lines delayed their arrival to their offices, many of them were supportive of CUPE 3903's right to strike and picket. Many picketers would engage in discussions with this group of drivers around the happenings of the university, specifically regarding 
the problematics of York's bargaining tactics. We would also listen to their suggested strategies of resistance and receive information about the upcoming negotiations between their respective unions and the administration. Further, with those who did not support the strike, we discussed the unequal inflation of the wages of York's senior administration and, more specifically, how it negatively impacted lower-level employees, like themselves.

The fourth category of drivers includes York University students, who were also directly impacted by the strike. Labour disruption resulted in the cancelling of $60 \%$ of classes, which were completely or partially taught by contract faculty and teaching assistants, in addition to the complete suspension of classes in various departments in solidarity with CUPE 3903. Students expressed various opinions about the strike, but much of their support thinned out as the strike went on. Further, students received conflicting, if not inaccurate, information about the labour dispute from the administration, which negatively impacted their overall support of CUPE 3903. For instance, the York University administration utilized dishonest communication tactics, such as buying a CUPE 3903 domain name and directing traffic to that website (Newswire, 2018). In addition to receiving conflicting communications, the students' graduation and courses were also put on hold, impacting their ability to apply to graduate programs, work summer jobs, and plan their summer vacations. As a result, most undergraduate students blamed us for the strike and regarded us as selfish. They accused us of taking them hostage, especially since the strike took place four weeks before the end of the academic year (although our collective bargaining ended in September 2017). The inability of undergraduate students to identify the York University administration as the source of the strike and the failure of CUPE 3903 to properly build bridges with them, was often reflected at the picket line. Few undergraduate students visited us, or their teachers, to express their solidarity.

Generally speaking, soliciting sympathy and support from the public required us to develop a mutual understanding of their grievances, especially in cases where we could or sought to link them to our own. Each of the categories mentioned above experienced a specific type of grievance with York
University and the 2018 strike. However, given the general precarity of the Canadian economy (Pupo, Duffy \& Glenday, 2017; Canadian Center for Policy Alternatives, 2018), in addition to the inflation of postsecondary educational fees (Statistics Canada, 2018), the main messages picketers tried to communicate (in line with CUPE 3903) to the general public were: 1) The precarious situation of contract faculty and graduate students at York University, and: 2) The unaffordability of university education. We felt that, given the current socioeconomic climate of Canadian society, specifically Toronto, where most people can relate to precarious work and the rising cost of education (as well as living), that this was the best way to elicit support and sympathy from people driving through the picket line. Below, this tactic is considered in more detail. More specifically, I draw on the social movement concept of "framing" to examine how picketers utilized mutual grievances between us and the general public to elicit their sympathy and thus (un)manage their feelings at the picket line.

\section{Findings and analysis}

\section{Role of the picket line}

Workers physically display the withdrawal of their labour during a strike through the use of picket lines, in which they demonstrate their anger with unjust working conditions, communicate their demands, and attempt to materially disrupt the employer's business. In essence, picket lines serve to communicate a central message to the employer that it is not "business as usual." In the case of the 2018 York University Strike, the employer was York University, and this message was delivered with the knowledge that the university could not function normally when more than $60 \%$ of the teaching body was on strike, thereby making it clear to the administration that they could not operate without respecting their employees.

Picket lines also offer a space for (re)politicization, as they provide a chance for picketers to construct solidarity with the general public in ways that may not otherwise be possible. For instance, at the Shoreham picket line, we - a diverse group of graduate students and contract faculty - met myriad workers and members from other industries and local communities. Prominent examples included 
the Ontario Federation of Labour, the Ontario Secondary School Teachers' Federation, Jane and Finch Action Against Poverty, CUPE 2424 (the union representing administrative, technical, library, counsellors, and nursing staff at Carleton University in Ottawa), the Ontario Coalition Against Poverty (OCAP), and other non-unionized workers. Given the diversity of these groups, it is unlikely that we would have crossed paths with these people regularly. Personally, while on the picket line, I met with unionized food delivery truck drivers, as well as other non-unionized drivers, who informed me about their experiences with striking. I also met a unionized factory worker from Sudbury, a city located about $400 \mathrm{~km}$ from Toronto, who informed me about their union's resistance strategies. These encounters offered an opportunity in which to (re)construct political solidarity with a wide range of political and social groups, permitting space to discuss and (re)imagine inclusive and non-exploitative political and economic policies between a diverse range of workers.

Most often, we would translate our CUPE 3903 grievances to strike bystanders by framing them in relation to the broader socio-economic problems within Canada. "Framing" is a cognitive tool commonly discussed in social movement literature (McAdam, 1996; Benford \& Snow, 2000; Olesen, 2005). Framing is defined as an interpretative schema, "selectively punctuating and encoding objects, situations, events, experiences and sequences of actions within one's present or past environment" (Snow \& Benford, 1992, p. 137). More specifically, it describes a process of ongoing negotiating, understanding, and meaning-making between variously located actors. During this process of negotiating and constructing meaning, attention is given to important features within a social movement, translating a specific set of grievances in a particular light to collectively mobilize activists from various sociopolitical locations (Snow \& Benford, 1988; Olesen, 2005). This, in turn, creates strong bonds between actors and non-adherents, such as picketers and bystanders in the context of a strike, thereby solidifying ties between them.

Regarding my experiences on Shoreham, I often used framing when speaking to people driving through the picket line. After greeting the drivers, I would ask them how they were doing in their own work, and whether or not their employer was offering them the salary and benefits that they felt they not only deserved but needed to live in a city like Toronto. I ended up identifying many common grievances around work precarity between CUPE 3903 members and the drivers with whom I spoke. In particular, just as we were resisting the precarious work conditions imposed onto us by York University, many of the drivers coming through our picket lines also experienced precarity at their jobs.

This finding makes sense, given that experiencing precarity at work is becoming an increasingly prevalent public issue within the Canadian economy (CCPA, 2018). In fact, a recent study done by the Canadian Centre for Policy Alternatives shows that $22 \%$ of Canadian professionals with a high school degree and skillset have precarious jobs (CCPA, 2018). Thus, it is not surprising that when I was car talking during the 2018 York University Strike, many drivers would share their struggles with difficult part-time and contract work, often expressing the negative impact that these jobs had on their everyday financial and physical well-being. Given that precarity at work can make securing housing and meeting basic human needs more difficult (Arnold \& Biongovi, 2013), people who experience it often have deep-seated feelings towards the issue. Thus, identifying common experiences of precarity among drivers and picketers created a space for us to relate to one another and foster mutual support.

In essence, by drawing on our shared work experiences with drivers, we were able to articulate our struggle in ways that resonated with them, which is essential for creating bonds with bystanders and thus preventing or de-escalating any potential violence at the picket line. Put simply, we used framing, a narrative tool that draws on cognitive structures to frame social issues in ways that connect individual lifeworlds to collective experiences, to construct shared understandings of our grievances, thereby mobilizing a diverse range of people around our cause (Snow \& Benford, 1988; Olesen, 2005). This demonstrates the argument made by McAdam, Tarrow and Tilly (2001) that frames "dignify claims, connect them to others, and help to produce a collective identity among claimants" ( $p$. 41, emphasis added). In the case of the 2018 York University Strike, collective identity was generated through the sharing, and subsequent politicization, 
of common experiences around work precarity.

Importantly, the cognitive framing that relates to an individual and collective experience is also associated with an emotional framing (Jasper, 1998; Flam, 2005). Every message that we, at CUPE 3903, communicated to the general public was aimed at provoking feelings of sympathy and support towards us, while simultaneously directing feelings of anger towards our employer: the York University administration. For example, during my face-to-face interactions with the public at the picket line, I always pointed out the problems of labour precarity and the rising costs of post-secondary education in a way that would provoke anger amongst the public, thereby potentially leading them to voice their opinions to and against the university.

Leading questions such as, "Can you afford to send your kids to university?" or "Have you witnessed the increase in the cost of course fees? "or "Do you feel secure at work and is your job providing you the means to survive?" often served as transformative emotional hooks that enabled us to connect to the hearts and minds of the drivers. For instance, some non-supportive undergraduate students changed their minds after these questions prompted them to think about the inaccessibility of post-secondary education or the worsening quality of the university itself. Parents of students would also reflect on the increasing yearly fees and student loans. With these examples in mind, it is clear that emotions played an important role in the framing process at the Shoreham picket line, whereby picketers mobilized personal experiences and feelings to create solidarity with bystanders. In this sense, picket lines are a space in which emotional and cognitive framing is co-constitutive, thereby challenging the rational paradigm and the rational-emotional dichotomy that dominated the field three decades ago.

\section{Forging support}

Drivers passing through our picket line expressed their support and sympathy with us in material and non-material forms. Many of them offered us hot beverages, the popular Canadian treat Timbits, homemade cooked food, snacks, face cream, hand heating pads, and umbrellas. Others conveyed their support by soliciting us to "stay strong," or telling us: "You should fight to get your rights," as one middle-aged woman of colour once told me. Others shared their own stories of labour precarity. One employee in the York University administration explained to me how the prevalence of short-term contracts in his understaffed non-academic department resulted in an insecure and overworked staff without good health and pension benefits. One student recalled the anxiousness that their contract faculty father felt a few years ago when his contract would be renewed less than two weeks before the start of each semester. The student then expressed their disappointment that nothing had changed.

Other bystanders expressed their support by sharing tactics and strategies from previous strikes that they had either been a part of or had personally witnessed. One older man informed me about a 6-month strike that he participated in during the sixties in Italy. Another driver suggested that CUPE 3903 members organize a picket line in front of the York University president's office, in order to bar her from entering it. Two members from UNIFOR, the largest private-sector union in Canada, shared picket line tips with me that they used during their three-week strike a few years back, in which more than 500 temporary and full-time workers formed a 24-hour picket line around the warehouse and distribution centers of Coca Cola in Brampton until their demands were met. These two individuals also kept encouraging us to adopt a hard picket line and completely block all entrances into the university. Their solidarity was so strong that they remained at the picket line longer than was necessary during one especially busy morning to shield picketers from a potentially violent driver who threatened to run us over. In this instance, solidarity was expressed through words and through actions.

However, not all car drivers immediately sympathized with us. With some, we needed to initiate a conversation in order to bridge the gap between our grievances and their concerns. These discussions, framed as "rational arguments", permitted us the ability to shift their emotions away from anger and toward sympathy. In one encounter, for example, I had the following conversation with a student at York University as they drove through the picket line:

(C refers to a car driver. $\mathrm{R}$ refers to me, Rana)

$C$ (in an angry tone): Till when you will be on 
strike? We are losing a semester because of your (expletive) strike?

R: Are you a student at York?

C: Yes. And I am unable to go to classes because of your (expletive) strike and your greed. I work hard to pay the fees, and now my classes are cancelled because of you.

$R$ : I understand your frustration. I am in the same position. I also pay the fees for my doctoral degree. But have you realized the bad shape of our classrooms? Of our labs? The dirtiness and dust, the leaking roof of the library. And that's not because York does not have money

\section{C: Yes, but that does not justify your-}

R: What about the increased fees in a publicly funded university?

C: Yes. My fees have increased since I started my degree 3 years ago.

R: Yes. The university has good profits, but they are invested in specific buildings, or in increasing the salary of top administrators.

C (in a calm way): Yeah.

R: While the contract faculty teachers and the teaching assistants live insecurely. We have to work in different places to be able to pay the bills - if we are lucky to find a job. How will this impact your learning?

\section{C: I do not see the connection.}

$R$ : When teachers are obliged to commute from one university to another to be able to get enough income to pay the bills because York is not offering them secure and full-time jobs. Or when teaching assistants have to work another job to be able to pay their fees and their bills, because their funding is below the poverty line. The quality of their teaching may be impacted.
C: Yeah. I get your point. So, what are we supposed to do to help you and get over the strike?

$R$ : Write to the administration. Join us at the picket line. Write to your MPP [Member of provincial parliament] about the strike. Let us all exercise some pressure on the administration to go back to the bargaining table. We want to bargain.

\section{C: Okay. Good luck.}

The above conversation exemplifies how, through dialogue, I was able to change the emotions of a student from anger to sympathy. During this conversation, the student ended up diverging his anger away from CUPE 3903 and towards York University, specifically blaming the university for increasing their student fees. Moreover, they came to understand the impact of the precarious situation of contract faculty and teaching assistants at York on their learning experience as a student. The student then ended the conversation by offering to help - a gesture that demonstrates a change in their temperament. Diverting drivers' anger towards the administration in this way was the ultimate goal we attempted to reach while encountering violent bystanders on the picket line.

\section{Collective expression of anger}

Importantly, and unfortunately, not all the conversations and encounters we had with drivers were fruitful in forging support. The disenchantment of drivers with our labour dispute and its manifestation at the picket line was expressed through various tactics of humiliation, shaming, and threatening. Hence, in the following sections, I will review stories of anger on the picket line, which were expressed in numerous ways. For one, anger can be collectively expressed in an effervescent manner, in which one person's overt expression of anger can influence others' feelings and expressions of anger. In the case of the 2018 York University Strike, this was specifically true when certain drivers received preferential treatment and got expedited, as discussed below. However, anger can also be externalized and projected onto the picketers by shaming us for our "unprofessionalism" and blaming 
us for their grievances.

The most stressful moments of the strike occurred when the general public would verbally threaten or abuse us. This was largely because the rage of one or a few angry drivers would often spread to the other drivers nearby. For example, if one car driver started to honk their horn aggressively, then other drivers would soon join in. This collective expression of anger and distress was intensified by the overt expression of one angry individual, which would then multiply as other drivers would join in, constituting a collective effervescence, or "intensification of a shared mood" (Collins, 2014, p. 299).

The intensification of anger occurred most often after we allowed specific cars to cross the picket line without waiting. At the onset of the strike, our union executive team gave special passes to the daycare workers at the university facilities, which allowed them to get expedited to the front of the picket line. The executive team also made an agreement with the ice arena facilities to expedite attendees of hockey tournaments in exchange for them blocking a private road, which they owned, that provided cars with an alternative route into the university, thereby allowing them to avoid the picket line altogether. In making this arrangement with the arena, we made sure that every car going to or through the campus had to pass through a picket line.

The special treatment of both the daycare employees and the hockey tournament attendees sparked the rage of other drivers, who questioned our integrity and subsequently created a wave of collective anger. One person accused us of offering preferential treatment to rich people, given that many attendees of the hockey tournaments own expensive cars. In one incident, a car driver violently confronted my colleague, humiliating him and spitting at him. At the same time, two other drivers joined in and began shouting and threatening to run us over. In another incident, an angry driver left their car, confronted me, and almost hit me. Another driver then joined them and knocked down some of the barriers at the picket line. In a third incident, an angry driver shouted at me, started pushing the barriers we had installed aside, and retrieved a bicycle wheel from their car to hit me. Other drivers then started honking and signalling to my colleagues, the picketers, to allow them to pass. These instances demonstrate how, specifically within the context of collective actions, anger can echo throughout a space as a result of the behaviours of one or a few enraged bystanders, emerging as a collective effervescence and thus creating a shared space of affectual violence that is often hard to manage.

\section{Weaponizing Shame}

Anger also emerged among drivers in the form of shaming. Shaming often serves as a tool for both political mobilization and demobilization (Goodwin \& Pfaff, 2001; Flam, 2005). It is a double-edged weapon that can either lead to participation in collective action or discourage people from active involvement in social movements (Flam, 2005). Goodwin \& Pfaff (2000) demonstrate how shaming served as a mobilizing tool for non-participants in various mobilizations in the United States and East Germany. They found that shaming passive community members for not participating in activism during the civil rights movement in the 1960s constituted a helpful tool to encourage these people to become more active in the movement. Here, Black activists would use emotional words to shame and embarrass these individuals into joining the civil rights movement.

Nevertheless, at the same time, activism is often considered to violate social norms (Becker, 1963; Lindblom \& Jacobsson, 2014). Thus, shaming can also be used as a tool through which to exhort individuals from engaging in activist behaviour, regulating them back into conformity (Flam, 2005). For instance, the vignette below exemplifies how a car driver attempted to shame CUPE 3903 into reconsidering our strike practices.

\section{C: "Why do you block the road?"}

R: "Good morning, sir. We are currently on strike at York University, and this is our picket line."

\section{C (angrily): "Who are you?}

$R$ : "We are the union that represents contract faculty and graduate students at the university. We teach $60 \%$ of the courses and

$C$ (interrupting me): You teach at the university, 
and you block the road?

$R:$ We are in a legal strike, and it is legal to -

$C$ (interrupting me again): You are a teacher, a tea-cher (emphasizing with louder voice). You should be teaching in the class.

\section{R: Exactly. I should be in-class teaching. But I} cannot teach if I live in insecurity and my -

\section{C: (interrupting and shouting at me): Shame} on you. You are a terrible teacher. You should be respectful and teach the students. Shame on you.

(closes his window and starts honking to express his discontent with the delay at the picket line.)

The above conversation demonstrates how a bystander can weaponize shame against protestors, discouraging them from pursuing our legal right to go on strike. At the Shoreham picket line, in particular, drivers sought to externalize their anger, projecting it onto us in order to make us feel ashamed for striking. Here, drivers would shame us by attempting to impose a sense of guilt onto our actions, making statements such as: "You should be ashamed of what you are doing," "You are a terrible teacher", or "You should not be a teacher". Further, these sentiments were often accompanied by body language and facial expressions, which signalled disgust, such as the shaking of one's head or the waging of their finger. These types of reactions are intended to belittle and demean us - and it sometimes worked. During the first weeks of the strike, and despite my deep belief that going on strike was the right thing to do, I felt embarrassed after I was unable to convince one angry driver about our right to establish a picket line. This is largely because angry drivers who shamed us did not attempt to listen to or understand our struggle, thereby making us feel dehumanized. Later on, however, I started to turn these instances of shame into teachable moments, telling drivers who sought to shame us that we were modeling how to demand that one's rights be taken seriously.

For many, our labour withdrawal and traffic obstruction represented a deviation from the normative image of how a university graduate student or a professor should behave, which, in turn, led them to shame us. Many believed that educational professionals should be in class, teaching students and preparing them for a better future. Thus, some drivers saw our labour withdrawal as a deviation from our professional objectives. Such instances of "shaming" demonstrate how emotions can be used in line with prevailing moral codes of conduct and belief systems to regulate the behaviours of protesters - people who are largely considered to be violating implied ethical tenets or common-sense notions - into conformity. In this instance, these beliefs included logics such as "teachers should be selfless" or "university teachers are financially secure".

In another instance, a middle-aged man responded to my explanation of the grievances we were facing by stating that: "I do not believe you," "I do not believe that teachers at the university face these problems". He then closed his car window to shut down further explanation. This driver had a hard time accepting the arduous labour conditions we live in and thus accused me of lying. Importantly, he continued to do this even after I handed him a leaflet that explained our wages, which CUPE 3903 produced to provide a counter-narrative to the university's propaganda. This exchange exemplifies how pre-existing beliefs and conceptions can interfere with solidarity building between the picketers and the general public, shutting down dialogue from the onset and thus expanding the rift between the two groups.

\section{Externalizing anger}

Emotions also infuse social movements in ways that are determined or informed by the larger social context in which they emerge. For instance, Canada is a neoliberal society operating within a global neoliberal market, whereby the culture of individual responsibility has become more and more dominant (Shamir, 2008). In a neoliberal context, the role of the government is redirected towards business interests and private profit-making, thereby alienating it from its duty to protect and support citizens (Larner, 2000; Liebenberg, Ungar \& Ikeda, 2013). Accordingly, individuals are increasingly taught to be mostly, if not solely, responsible for their financial well-being, 
healthcare, education, and skillset (Raddon, 2012; Liebenberg, Ungar \& Ikeda, 2013). Relatedly, discourses of individual responsibility have become pervasive, routinely selling citizens the idea that managing every and all aspects of their life is a form of individual empowerment and self-improvement (Brock, 2012). However, this process of responsibilization obscures the structural factors that impact individuals' everyday behaviours, many of which this paper has already noted, such as precarity in the post-secondary education or the overall lack of good jobs available in the Canadian economy. Thus, within this neoliberal culture, there is no doubt that some drivers coming through our picket line would blame the picketers for their grievances, as elucidated in the below conversation:

R: Good morning, sir. How are you doing today?

C: Well, I will be better if I can reach my work on time. What is happening here?

R: We are on strike at York University, and this is our legal picket line,

\section{C (looking confused): Strike. What for?}

$R:$ We are the contract faculty and the graduate students. We are asking for job security and funding to live above the poverty line.

\section{C: What, what job security?}

$R$ : We have contracts that are renewed every semester, we do not have full-time jobs with benefits, and we have to work in different places to be able to pay the bills.

C: If you are not happy with your job, get another job.

R: But we are educators, and this is our job. And this is a publicly funded university. Why not change our working conditions?

$C$ (in an affirmative tone): Change your job. If you are not happy, change your job and do not go on strike. You cannot depend on our taxes to fund your job. Find something else.

$R$ : Most of the jobs these days in Canada have the same insecurity. So it is time that we ask for our fundamental rights.

C: And do you think you will be able to change it?

R: The university cannot run without our labour, and we are on strike to be able to change the situation.

C: No one will change the situation. This is it. Accept it and go find another job if you are not happy. You can live a decent life if you change your job. You should not depend on our taxes. It is up to you. Now open this road for me. I need to go.

\section{$R$ : We will try to change it.}

\section{C: I need to go (in an angry tone)}

R: We allow two cars every 4 minutes. Your wait time is less than 15 minutes.

\section{C: Find another job (Expletive).}

In the above conversation, the driver is externalizing their anger as a result of waiting at the picket line by blaming the strikers for their personal economic problems. Instead of understanding the root causes of economic distress that led to the strike, the driver blamed us for our own financial distress and job insecurity. This exemplifies the process of responsibilization typical to neoliberalism, in which individuals are constructed as solely accountable for their success and/or failure, thereby disregarding the structural problems that encourage these successes and/or failures in the first place. These structural problems include but are not limited to race, gender, class, and immigration status (Musolf, 2003).

The normalization of discourses of individual responsibility is clearly manifested in the driver's specific statement: "You can live a decent life if you change your job. You should not depend on our taxes. It is up to you". Such statements shift the responsibility of job precarity, job loss, and low 
funding away from the employer, York University, and onto us, the picketers. In turn, the driver's anger is, in their mind, justified, as the picketers are not doing their best to live a decent life. Similarly, their lawful act of blocking the road or delaying entrance into the university is rendered deviant. This particular exchange illuminates the effects of hegemonic neoliberal thinking on contemporary social movements: highlighting how such thinking permits the general public the rhetoric they need to portray protestors as lazy and irresponsible workers who are shirking their responsibilities to the economy and are thus unworthy of sympathy and solidarity.

\section{Discussion and conclusion}

This article draws on data collected through personal experience and existing literature to highlight the often-marginalized role that the emotions of the general public play in shaping the atmosphere of picket lines. More specifically, this paper reflects upon my personal encounters with drivers at the Shoreham picket line during the 2018 York University Strike to examine the role of bystanders' emotions in social movement organizing. In order to do this, I provide different examples from my time as a front-line communicator or "car talker" to display the spectrum of emotions that bystanders are capable of, ranging from sympathy and support to collective anger and shaming.

Recognizing that cognitive and emotional framing are co-constitutive, I argue that emotional management is closely inter-related to the message that picketers communicate to the general public. Acknowledging the existing economic problems in Canadian society, such as the dominance of precarity in the job market and the unaffordability of postsecondary education, I highlight how CUPE 3903 sought to elicit communal sympathy and support by bridging our grievances with those of the general public. This is otherwise known as the tactic of framing. In using this discursive practice, we were able to evoke solidarity from many of the drivers passing through the picket line, successfully changing their opinions and thus mobilizing their support.

However, at each encounter, I only had a couple of minutes to interact with the driver, which usually started with my salutation and introduction and would then transition into a discussion. These engaged interactions were usually multi-directional: I would communicate my message to the driver, who would then respond to me. Yet, the relative success of these exchanges was also impacted by the pre-existing beliefs of the drivers and their emotional well-being at the time of the encounter. For instance, some encounters only reinforced common-sense belief systems, such as the ineffectiveness of strikes and the neoliberal responsibilization of financial well-being. To demonstrate this point, I engage one example in which a driver blamed us for our poor financial well-being, and consequently shut down any possibility of us forging solidarity with them. Other encounters illustrate how anger has the power to be collectively effervescent, making it harder to manage the emotions of the public. Lastly, picketers can never really know the emotional and physical status of drivers before they reach the picket line. For instance, I met individuals who had just finished their night shift and were passing through the picket line to go home to rest before starting the day shift for their second job. I would watch these individuals sleep in their cars while waiting for their turn to pass, unable to let them through. Another time, I accidentally made a mother sob because my interaction with her triggered the severe anxiety she had around her child with autism. These and similar instances illustrate the fact that bystanders bring a complex constellation of emotions to the picket line experience that picketers themselves cannot reasonably manage. Future research should further investigate the issues that this poses to the longevity of social movement organizing.

The ways in which social agents manage the emotions of the general public are understudied in social movement literature on the ground. This relative blindness to bystanders' emotions negatively impacts researchers' understanding of the longevity of social movements, as it promotes a perspective that negates what a movement looks and feels like to the people who animate it. During the 2018 York University Strike, picket lines were sites of escalated verbal and physical violence against picketers. This paper demonstrates how some drivers intended to shame picketers by humiliating, threatening, and demeaning us. In extreme cases, bystanders physically assaulted picketers, by either 
spitting on us, knocking down our road barriers, throwing objects at us, or even hitting us with their fists. Unsurprisingly, such violence was the main contributor to the thinning of the picket lines, as it traumatized many of the picketers. These findings suggest that managing the emotions of the drivers by de-escalating potential violence was of utmost importance for the strike, as it shaped the durability and density of the picket lines. It also points to the importance of building bonds with bystanders around mutual grievances in order to protect against such violence. Hence, by foregrounding these issues and providing an empirical study of the interactions between picketers and the general public, this article contributes to the growth and development of the sociology of social movements.

As a social movement researcher and scholaractivist, I am committed to producing knowledge alongside the movements I study. This requires an ethical commitment to the growth and prosperity of these social movements and to produce knowledge that will positively impact them. Drawing on personal experiences with social movement organizing to study and analyze a movement's development (in this case, I drew on my experiences as an active member of the rank and file of CUPE 3903 to engage the 2018 York University Strike) allows scholar-activists to examine the micro-dynamics that contribute to the development of a social movement and whether or not said movement is effective. My direct engagement with the drivers at the picket line allowed me to offer an analysis of their emotions at that specific site on inquiry. Epistemological practices and knowledge productions stemming from these and similar types of ground-level experiences are of particular importance to the study of social movements and are useful for both academic and activist fields, as such research provides a firsthand experience of activists' interactions with the general public as they fight to protect their rights and dignity.

\section{References}

Adams, J. (2002). Gender and social movement decline: Shantytown women and the prodemocracy movement in Pinochet's Chile. Journal of Contemporary Ethnography, 31, 285-322.

Aminzade, R. \& McAdam, D. (2002). Emotions and contentious politics. Mobilization: an International Quarterly, 7(2), 107-109.

Arnold, D \& Biongovi, J.R. (2013). Precarious, informalizing, and flexible work: Transforming concepts and understandings. American Behavioural Scientist, 57(3), 289-308.

Becker, H. S. (1963). Outsiders: Studies in the Sociology of Deviance. New York: The Free Press.

Benford, R., \& Snow, D. (2000). Framing processes and social movements: An overview and assessment. Annual Sociological Review, 26, 61139.

Benski, T. (2011). Breaching events and the emotional reaction of the public. In H. Flam \& D. King (Eds.), Emotions and social movements (pp.57-78). London and New York: Routledge.

Bosco, F. J. (2006). The Madres de Plaza de Mayo and three decades of human rights' activism: Embeddedness, emotions, and social movements. Annals of the Association of American Geographers, 96(2), 342-365.

Brock, D. (2012) Thinking about power: exploring theories of domination and governance. In D.

Brock, R. Raby \& M.P Thomas (Eds.), Power and everyday practices (pp.11-32). Toronto: Nelson Education.

Buechler, S. (1999). Social Movements In Advanced Capitalism. Oxford: University Press.

Cadena-Roa, J. (2002) Strategic framing, emotions, and superbarrio - Mexico City's masked crusader. Mobilization, 7(2), 210-16.

Canadian Center for Policy Alternatives. (2018, August 21). More than 1 in 5 Canadian professionals in precarious jobs. Retrieved from https://www.policyalternatives.ca/newsroom/ news-releases/more-1-5-canadian-professionalsprecarious-jobs-report.

Collins, R. (2014). Interaction ritual chains and collective effervescence. In C.Scheve \& M. Salmella (Eds.), Collective emotions, perspectives from psychology, philosophy and sociology (pp. 299- 311). Oxford: Oxford University Press.

CUPE 3903. (2018). What are the main issues? Retrieved from https://3903.cupe.ca/ students/\#issues

Diani, M. (1995). Green Networks. A Structural Analysis of the Italian Environmental Movement. Edinburgh, University Press Ltd.

Flam, H. (2005). Emotions' map: A research agenda. In H. Flam \& D. King (Eds.), Emotions and social movements (pp.19-40). London and New York: Routledge.

Goodwin, J. \& Pfaff, S. (2001). Emotion work in high-risk social movements: managing fear in the U.S. and Eastern German civil rights movements. In J. Goodwin, J. Jasper \& F. Polletta (Eds.), Passionate Politics (pp.282-302). Chicago: Chicago University Press. 
Goodwin, J., Jasper, J. M., \& Polletta, F. (2000). The return of the repressed: The fall and rise of emotions in social movement theory. Mobilization, $5(1), 65-83$.

Goodwin, J., Jasper, J. M., \& Polletta, F. (2001). Why Emotions Matter. In J. Goodwin, J. Jasper \& F. Polletta (Eds.), Passionate Politics (pp.1-24). Chicago: Chicago University Press.

Gould, D. B. (2015). The emotion work of movements. In J. Goodwin \& J.M. Jasper (Eds.), The social movements reader: cases and concepts 3rd Edition (pp. 254-265). Malden, MA: John Wiley \& Sons, Ltd.

Jasper, J. (1998). The emotions of protest: affective and reactive emotions in and around social movements. Sociological Forum, 13(3), 397-424.

Jasper, J. (2010). Social Movement Theory Today: Toward a theory of action?. Social Compass 4(11), 965-76.

Jasper, J. M. (2011). Emotions and social movement: twenty years of theory and research. The Annual Review of Sociology, 37, 285-303.

Jasper, J. M. \& Poulsen, J.D. (1995). Recruiting strangers and friends: Moral shocks and social networks in animal rights and anti-nuclear protests. Social Problem, 42(4), 493-512.

Klatch, R. (2004). The underside of social movements: The effects of destructive affective ties, Qualitative Sociology, 27, 487-509.

Larner, W. (2000). Neoliberalism: Policy, ideology, governmentality, Studies in Political Economy, 63, 5-25.

Liebenberg, L., Ungar, M. \& Ikeda, J. (2013). Neo-liberalism and Responsibilisation in the discourse of service workers. British Journal of Social Work, 45 (3), 1-16.

Lindblom, J. \& Jacobsson, K. (2014). A Deviance Perspective on Social Movements: The Case of Animal Rights Activism. Deviant Behavior, 35, 133-151.

McAdam, D. (1996). The framing function of movement tactics: strategic dramaturgy in the American civil rights movement. In D. McAdam, J. McCarthy \& Mayer Zald (Eds.), Comparative perspectives in social movements: political opportunity, mobilizating structures and cultural framings (pp.338-356). Cambridge: Cambridge University Press.

McAdam, D., Tarrow, S. \& Tilly, C. (2001). Dynamics of Contention. Cambridge: Cambridge University Press.

McCarthy, J. \& Zald, M. (1977). Resource mobilization and social movements: A partial theory. American journal of sociology,1212-1241.

Meyer, D. (2004). protest and political opportunities.
Annual Review of Sociology, 30, 125-145.

Musolf, G.R. (2003). Social Structure, Human Agency ad Social Policy, International Journal of Sociology and Social Policy, 23(6), 1-12.

Newswire. (2018, March 22). Citing 'dishonest communications,' CUPE 3903 files three unfair labour practices complaints against York University. Retrieved from https://www. newswire.ca/news-releases/citing-dishonestcommunications-cupe-3903-files-three-unfairlabour-practices-complaints-against-yorkuniversity-677653963.html

Norgaard, K. M. (2006). "People want to protect themselves a little bit": Emotions, denial, and social movement nonparticipation. Sociological inquiry, 76(3), 372-396.

Olesen, T. (2005). The uses and misuses of globalization in the study of social movements. Social Movement Studies, 4(1): 49-63.

Perry, E.J. (2002). Moving the masses: emotion work in the Chinese revolution. Mobilization, 7(2), 111-128.

Pupo, N., Duffy, A. \& Glenday, D. (2017). Crises in Canadian work. Oxford: Oxford: University Press.

Raddon, M.B. (2012). Financial fitness: The political and cultural economy of finance. In D. Brock, R. Raby, \& M.P. Thomas (Eds.), Power and everyday practices (pp.223-246). Toronto: Nelson Education.

Shamir, R. (2008). The age of responsibilization: on market-embedded morality. Economy and Society, 37(1), 1-19.

Snow, D. \& Benford, R. (1992). Master frame and cycles of protest. In A. Morris \& C. Mueller (Eds.), Frontiers in social movement theory (pp.133-155). New Haven: Yale University.

Statistics Canada, 2018. Canadian undergraduate tuition fees by field of study. https://www150.statcan.gc.ca/t1/tb11/en/ cv.action?pid=3710000301.

Tarrow, S. (1998). Power in movement: Social movements and contentious politics. Cambridge: Cambridge University Press.

Taylor, V. (1995). Watching for Vibes: Bringing emotions into the study of feminist organizations. In M. M. Ferree and P. Y. Martin (Eds.), Feminist organizations: Harvest of the new women's movement (pp. 223-233). Philadelphia: Temple University Press.

Van Ness, J. \& Summers-Effler, E. (2018). Emotions in social movements. In D.A. Snow, S.A. Soule, H. Kriesi, \& Holly J. McCammon (Eds.), The wiley blackwell companion to social movements, Second Edition (pp. 411-428). Oxford: Wiley Blackwell. 


\section{Appendix A}

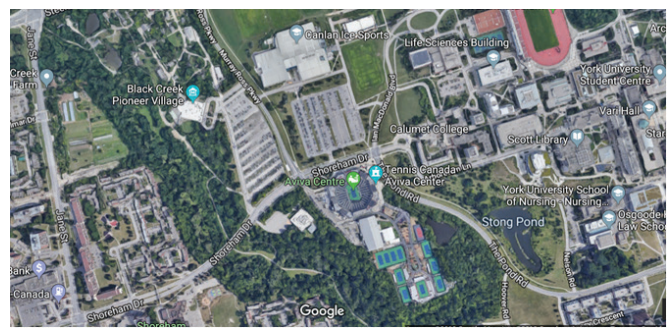

Figure 1: A map showing the location of Shoreham drive

\section{Acknowledgments}

The author is indebted to Jade Crimson Rose Da Costa, Kaitlin Peters, Giovanni Carranza and Jana Borras, and the participants at the sociology graduate symposium 2019, for their constructive and valuable comments.

\section{Author biography}

Rana Sukarieh is a Ph.D. candidate in Sociology at York University, Toronto, Canada. Her dissertation focuses on a (re)conceptualization of political solidarity among transnational activists, with focus on the Palestinian Boycott Divestment and Sanctions (BDS) movement. Her specific question examines the (dis)continuity of solidarity with the BDS movement and the process of transcending activists' differences in order to build a sustained solidarity. Rana's research interests are in the areas of transnational social movements, social movements and political economy in the Middle East, critical qualitative research and post-colonial studies. She currently teaches at the American University of Beirut. She holds a B.A in economics from the American University of Beirut, Hons. B.A. in Sociology and M.A in sociology from York University. She is a recipient of the Social Sciences and Humanities Research Council award (SSHRC), the Ontario Graduate Studies award (OGS), and the Nathanson Centre on Transnational Human Rights, Crime and Security award at York University. 